\title{
Effectiveness of the National Program for Community Empowerment (PNPM) for Infrastructure Development Accelerated and Geoplanology in District of Marpoyan Damai, Pekanbaru
}

\author{
Riry Fatriadi ${ }^{1,}$, Febby Asteriani ${ }^{1}$, Catur Cahyaningsi ${ }^{2}{ }^{2 *}$

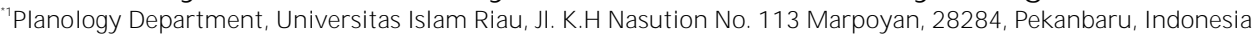 \\ ${ }^{2}$ Department of Geological Engineering, Universitas Islam Riau, Jl. K.H Nasution No. 113 Marpoyan, 28284, Pekanbaru, Indonesia
}

\author{
* Corresponding author : caturcahyaningsih@eng.uir.ac.id \\ Tel: $+62-82284013121$ \\ Received: Feb 1, 2017. Revised : 15 Feb 2017, Accepted: Feb 20, 2017, Published: 1 March 2017 \\ DOI: 10.24273/jgeet.2017.2.1.30
}

Abstract

Since 2007 PNPM Urban realize that poverty is a structural problem and multi-dimensional. In PNPM Urban perspective , the complexity of the various dimensions of poverty - related social , political , economic, and asset . this research aim is to know the Effectiveness of the National Program for Community Empowerment for Infrastructure Development Accelerated. In this research, the authors use an explanatory survey research methods. Selected number of samples in the analysis of the effectiveness of PNPM Urban infrastructure improvements are stakeholders involved in PNPM Urban population in the research area of all stakeholders involved in PNPM Urban in District Marpoyan Damai , the authors take purposively respondents who meet the criteria and are associated with research.

The results showed that increasing road infrastructure with the PNPM Mandiri. The average improvement of road infrastructure after the PNPM Urban amounted to $35.8 \%$ The average increase in the quality of infrastructure before the PNPM Urban program is only at $4.4 \%$ per year. This indication shows that roads infrastructure and the quality of the road surface to be increased significantly in the presence of the PNPM Urban Marpoyan Damai in the District . From interviews with relevant stakeholders PNPM Urban, respondents said PNPM Urban was very effective against the improvement of infrastructure in District Marpoyan Damai . Respondents argue that any proposed activity in infrastructure al ways realized by PNPM Urban

Geological condition of study consists of alluvium Sand, Gravel, Clay, Peat Swamp, Plant Remain in Quaternary age. There are two anticline in this area that is part Western and Southern and fault inferred direction Northwest-Southeast in the middle area of research so that the topography of the area of research a bit wavy and faulted that need observation on landuse planning such as drainage, airport, residential and availability of clean water.

Keywords: Poverty, effective, Geology, Land Use Planning

\section{Introduction}

Poverty is a cross sectors problems, cross area and cross generation Problem, so to handle an integrated comprehensive and sustainable approach is required. In PNPM Urban perspective, the complexity of poverty related to various dimensions of social, political, economic, and assets. Birds should start from the social aspect of humanity fundamentally. Root causes of poverty are not solely economic issues and more on the issue of inequality, due to the collapse of human values and the neglect of governance principles good governance becomes the basis for PNPM Urban to build social capital and start a social change on an ongoing basis (Kuncoro, 2004; Suryono, 2001 \& Tri Wahyu, 2011).

Weak social capital also encourages a shift in public behavior that is farther away from the spirit of independence, solidarity and concern to solve the problem together. Institutional conditions led people who are not rooted and can not be trusted are generally thrives in situations where the general public is not helpless. The powerlessness of society in addressing and cope with situations in their environment, which in turn encourages indifference, do not care, do not believe in themselves, relying on outsi de help to overcome the problems faced, not independent, as well as waning orientation of moral and values sublime in the society, especially the sincerity, fairness and honesty. (Arikunto, 1998; Ministry of National Education, 2003; George Odunga, 2013; Nawawi, 1998; Sedarmayanti, 2001; Todaro, 2000; Wahab, 2004)

Geology and Regional Planning is required to determine the rocks composition of rocks in the research area. (Cahyaningsih, 2016); (Mairizki and 
Cahyaningsih, 2017); (Putra and Choanji, 2016), (Suryadi, 2016) \& (Yuskar, 2016).

\section{Aim}

The purpose of this study was to examine the effectiveness of PNPM Urban Pekanbaru to accelerate infrastructure development and regional geology planning in the district Marpoyan, Pekanbaru.

\section{Methods}

Explanatory survey research methods using for this research. Survey research is an investigation conducted to obtain the facts from existing symptoms and seek explanations are factual and explanatory means explaining events or circumstances right now, and explain events or circumstances that would come.

\subsection{Research Variables}

The variables of research can be seen in Table 1.

\subsection{Sampling Technique}

The samples were selected in the analysis of the effectiveness of PNPM Urban against improvement of infrastructure are stakeholders involved in PNPM Urban at the study site from the population of all stakeholders involved in PNPM Urban in the Marpoyan Damai Peace.

Number of KSM (Self Help Groups) that consists of community groups and stakeholders directly involved in PNPM Urban is $80 \mathrm{KSM}$. In conducting the sample size calculation was based on an error of $5 \%$

Using tables (Sugiyono, 2000). From the table it can be determined the number of samples taken in the district. Marpoyan Damai Damai with a population of 80 is 66 samples (Table 2 ).
KSM determination on each MFI usingtechnique, simple random sampling meaning that researchers sampled randomly from the KSM amount in an $\mathrm{MFI}$.

\subsection{Geological Analysis}

Regional geological map sheets Pekanbaru No 0816 from Coordinating Surveys and Mapping Agency (Bakosurtanal) was used to analyze rock composition of age of rocks. This analysis is done in of Geological Basic Laboratory Universitas Islam Riau.

\section{Result}

\subsection{Analysis of public Participation in the urban} PNPM in District Marpoyan Damai

PNPM Urbanis a process of learning communities to alleviate poverty. The learning process is actually a process of education, meaning that changes can occur through a process of education, accompanied by a facilitator in the Village / Village goals. The stages of PNPM Urban Cycle can be seen in Table 3.

In District Marpoyan Damai, community participation in the implementation of PNPM Urban cycle is very high. Be it in the Citizen Readiness Rembug Socialization, FGD (Focus Group Discussion) RK (Reflection Poverty), Mapping Governmental (PS), election of members of the MFI base level, PNPM volunteers, as well as in the preparation of the Medium Term Plan Poverty Reduction Program (PJM Pronangkis). Every society, both men and women play together to solve the problem of poverty. Community participation in the District of Marpoyan Damai each village can be seen in Table 4.

Table 1 . Effectivity variable of PNPM Mandiri at city on Acceleration of Infrastructure Development

\begin{tabular}{clll}
\hline Variable & \multicolumn{1}{c}{ Indicator } & \multicolumn{1}{c}{ Sub Indicator } \\
& & & \\
\hline Infrastructure & Society & $\checkmark$ & Public participation in PNPM MP \\
& Participation & $\checkmark$ & Improvement of quality of infrastructure development \\
& - & Improving the & $\checkmark$ Contributions of public funds on infrastructure \\
& quality of & development financing \\
& infrastructure & \\
& development & \\
\hline
\end{tabular}

Table 2. Number of Sampling

\begin{tabular}{cccc}
\hline No. & microfinance & KSM & Total Sample \\
\hline 1 & Tangkerang West Makmur & 19 & 16 \\
2 & Damai Indah Makmur & 17 & 14 \\
3 & Jaya woner & 14 & 11 \\
4 & Maharatu Makmur & 8 & 7 \\
5 & East Sidomulyo Sorcerer & 22 & 18 \\
& Total & 80 & 66 \\
\hline
\end{tabular}

Source: Observation and analysis in 2011 
Table achievement of participation of the population in the District of Marpoyan Damai above can be seen that, every activity on theof stages PNPM Urban Cycle performed with indicators set every village in the district Marpoyan Damai has been reached, Even enthusiastic residents in participating in every activity is high enough, it can be seen in Table 4 that any activities carried out in excess of the specified indicators. Every citizen of both men and women have equal rights. They jointly play an important role for the implementation of each activity of PNPM Urban in District Marpoyan Peace.

The education process is conducted in the District of Marpoyan Damai has an impact on public awareness. So grows the critical consciousness of society, such as in the implementation of the Poverty Reflection (RK) which foster the values of justice, equality, mutual understanding, and mutual care to the problems of others. District of Marpoyan together to learn to identify, analyze patterns of relationships (interactions) they are in social life, causing equal and equitable relationship. Integrated policy and the provision of appropriate information can stimulate the development of infrastructure, increase community participation, creating community awareness.

Social relationships in a fair, people in the District of Marpoyan Damai has grown values appreciate each other, give each other, understand each other so that they are empowered to selfreliance in poverty reduction. Through this learning process, it is expected the public is able to change the mindset and attitude as human behavior is responsible for running his nature as a human, that human beings are capable of providing the potential that exists within him for the welfare of themselves and their surroundings.

$\frac{\text { Table 3. PNPM Urban Cycle Stages }}{\text { Cycle }}$

\begin{tabular}{|c|c|c|c|}
\hline & $\begin{array}{l}\text { Principles of } \\
\text { Community }\end{array}$ & Values & Mindset \\
\hline $\begin{array}{l}\text { Rembug Community } \\
\text { Preparedness (RKM) }\end{array}$ & $\begin{array}{l}\text { Participation: learning } \\
\text { communities decide } \\
\text { consciously efforts to } \\
\text { solve the problems } \\
\text { they need }\end{array}$ & $\begin{array}{l}\text { Justice and equality: all } \\
\text { layers of society has the right } \\
\text { to obtain information and } \\
\text { make decisions }\end{array}$ & $\begin{array}{l}\text { Society merupaka subject of } \\
\text { development and reserve the } \\
\text { right to determine their own } \\
\text { destiny without coercion from } \\
\text { outside parties, but based on } \\
\text { their critical kesanadan }\end{array}$ \\
\hline Reflection poverty (RK) & $\begin{array}{l}\text { Participation: } \\
\text { engagement to } \\
\text { determine the main } \\
\text { problems of poverty }\end{array}$ & $\begin{array}{l}\text { justice and equality, mutual } \\
\text { understanding and mutual } \\
\text { care for the problems of } \\
\text { others. Honesty to } \\
\text { acknowledge the problem }\end{array}$ & $\begin{array}{l}\text { The main causes of poverty: the } \\
\text { erosion of human values, all } \\
\text { parties are responsible in } \\
\text { solving the problem of poverty. } \\
\text { People able to analyze the } \\
\text { causal problem of poverty }\end{array}$ \\
\hline $\begin{array}{l}\text { mapping Governmental } \\
\text { (PS) }\end{array}$ & $\begin{array}{l}\text { participation, } \\
\text { transparency of } \\
\text { information in } \\
\text { exploring the potential } \\
\text { and problems together }\end{array}$ & $\begin{array}{l}\text { Caring about the problems of } \\
\text { the poor, mutual respect, } \\
\text { mutual understanding, } \\
\text { equality in the activities of }\end{array}$ & $\begin{array}{l}\text { the community were able to } \\
\text { conduct a study and penelitiah } \\
\text { simple view of the problems in } \\
\text { the region }\end{array}$ \\
\hline Development BKM & $\begin{array}{l}\text { democracy, } \\
\text { participation, } \\
\text { decentralization in the } \\
\text { institutional } \\
\text { development of } \\
\text { representative } \\
\end{array}$ & $\begin{array}{l}\text { Honesty, fairness, equality, } \\
\text { volunteerism becomes a } \\
\text { commitment to all citizens }\end{array}$ & $\begin{array}{l}\text { people were able to organize } \\
\text { themselves in determining who } \\
\text { should lead }\end{array}$ \\
\hline $\begin{array}{l}\text { PJM Pronangkis } \\
\text { (participatory planning) }\end{array}$ & $\begin{array}{l}\text { participation, } \\
\text { transparency, } \\
\text { democracy in the } \\
\text { learning process } \\
\text { preparing plans to } \\
\text { meet community } \\
\text { needs }\end{array}$ & $\begin{array}{l}\text { justice, honesty and } \\
\text { togetherness in an effort to } \\
\text { meet the need to address the } \\
\text { issue of poverty can be } \\
\text { tackled }\end{array}$ & $\begin{array}{l}\text { society was able to plan the } \\
\text { program. Society has the } \\
\text { responsibility for planning. }\end{array}$ \\
\hline KSM organizing & $\begin{array}{l}\text { participation, } \\
\text { democracy, } \\
\text { accountability, within } \\
\text { the group as social } \\
\text { capital }\end{array}$ & $\begin{array}{l}\text { Justice, honesty, equality, } \\
\text { mutual care among group } \\
\text { members, mutual } \\
\text { understanding, mutual } \\
\text { respect and mutual trust }\end{array}$ & $\begin{array}{l}\text { society capable of organizing } \\
\text { itself in society }\end{array}$ \\
\hline
\end{tabular}

Source: Module Review the Implementation Cycle PNPM Urban 
Table 4. Achievement Participation Residents in the District Marpoyan Damai

\begin{tabular}{|c|c|c|c|c|c|c|c|c|c|c|c|c|}
\hline \multirow[b]{2}{*}{ Village } & \multirow[b]{2}{*}{ Event } & \multicolumn{10}{|c|}{ AchievementParticipation \& Women's Adult Population } & \multirow[b]{2}{*}{$\begin{array}{c}\text { Percentage } \\
\text { Achievemen } \\
\text { t of } \\
\text { Women's } \\
\text { Participatio } \\
\text { n }\end{array}$} \\
\hline & & $\begin{array}{l}\text { Total } \\
\text { Population } \\
\text { Adult }\end{array}$ & $\begin{array}{c}\text { Indicator } \\
\text { 10\%(PA MFI } \\
40 \% \text { PJM } \\
5 \%\end{array}$ & $\begin{array}{c}\text { Realizatio } \\
\mathrm{n}\end{array}$ & $\begin{array}{l}(+1 \\
-)\end{array}$ & $\begin{array}{l}\text { Achieve } \\
\text { ment }\end{array}$ & $\begin{array}{c}\text { Percentage } \\
\text { of } \\
\text { Accomplish } \\
\text { ment } \\
\text { Participatio } \\
\text { n Population } \\
\text { Adult } \\
\end{array}$ & $\begin{array}{l}\text { Indicator } \\
40 \% \text { of } \\
\text { women } \\
\text { (Tim PS } \\
50 \%\end{array}$ & Realized & $\begin{array}{l}(+1 \\
-)\end{array}$ & $\begin{array}{l}\text { Achieve } \\
\text { ment }\end{array}$ & \\
\hline \multirow{7}{*}{$\begin{array}{l}\text { Tangkerang } \\
\text { Barat }\end{array}$} & Socialization and RKM & 13261409 & & 13257 & 83 & achieved & $11 \%$ & 530.28 & 586 & 56 & achieved & $42 \%$ \\
\hline & Volunteers & 11751194 & & 11751 & 19 & Reached & $10 \%$ & 470.04 & 494 & 24 & achieved & $42 \%$ \\
\hline & FGD RK & 12251295 & & 12253 & 70 & achieved & $11 \%$ & 490.12 & 533 & 43 & achieved & $42 \%$ \\
\hline & PS & 12251307 & & 12253 & 82 & achieved & $11 \%$ & 490.12 & 547 & 57 & achieved & $42 \%$ \\
\hline & Tim PS & 12251249 & & 12253 & 24 & achieved & $10 \%$ & 631 & 613 & 18 & achieved & $51 \%$ \\
\hline & $\begin{array}{l}\text { Election of Members of the } \\
\text { MFI }\end{array}$ & 49014945 & & 12253 & 44 & achieved & $40 \%$ & 1960.48 & 2000 & 40 & achieved & $41 \%$ \\
\hline & Preparation of PJM & 613641 & & 12253 & 28 & achieved & $5 \%$ & 245.06 & 277 & 32 & achieved & $44 \%$ \\
\hline \multirow{7}{*}{$\begin{array}{l}\text { Tangkerang } \\
\text { Tengah }\end{array}$} & Socialization and RKM & 31417 & 3142 & 3210 & 68 & achieved & $10 \%$ & 1257 & 1312 & 55 & achieved & $41 \%$ \\
\hline & Volunteers & 31423211 & & 31417 & 69 & achieved & $10 \%$ & 1256.68 & 1317 & 60 & achieved & $42 \%$ \\
\hline & FGD RK & 32673307 & & 32667 & 40 & achieved & $10 \%$ & 1306.68 & 1352 & 45 & achieved & $41 \%$ \\
\hline & PS & 32673307 & & 32667 & 40 & achieved & $10 \%$ & 1306.68 & 1363 & 56 & achieved & $42 \%$ \\
\hline & Tim PS & 32673300 & & 32667 & 33 & achieved & $10 \%$ & 1633 & 1674 & 41 & $\begin{array}{l}\text { Completi } \\
\text { ons }\end{array}$ & $51 \%$ \\
\hline & $\begin{array}{l}\text { Election of Members of the } \\
\text { MFI }\end{array}$ & 13067 & 32667 & 13099 & 32 & achieved & $40 \%$ & 5226.72 & 5261 & 34 & Reached & $40 \%$ \\
\hline & Preparation of PJM & 16331670 & & 32667 & 37 & achieved & $5 \%$ & 653.34 & 693 & 40 & achieved & $42 \%$ \\
\hline
\end{tabular}


Table 5. Continued

\begin{tabular}{|c|c|c|c|c|c|c|c|c|c|c|c|c|}
\hline \multirow[b]{2}{*}{ Village } & \multirow[b]{2}{*}{ Activity } & \multicolumn{10}{|c|}{ PopulationParticipation Achievement Adult \& Women } & \multirow[b]{2}{*}{$\begin{array}{l}\text { Percentage } \\
\text { Achievement } \\
\text { of Women's } \\
\text { Participation }\end{array}$} \\
\hline & & $\begin{array}{l}\text { Total } \\
\text { Population } \\
\text { Adult }\end{array}$ & $\begin{array}{c}\text { Indicator } 10 \% \\
\text { (PA MFI } 40 \% \\
\text { PJM 5\% }\end{array}$ & $\begin{array}{l}\text { Realiz } \\
\text { ation }\end{array}$ & $\stackrel{(+/-}{)}$ & $\begin{array}{c}\text { Achieveme } \\
\text { nt }\end{array}$ & $\begin{array}{c}\text { Percentage of } \\
\text { Accomplishme } \\
\text { nt } \\
\text { Participation } \\
\text { Population } \\
\text { Adult }\end{array}$ & $\begin{array}{l}\text { Indicator } 40 \% \\
\text { of women } \\
\text { (Tim PS 50\% }\end{array}$ & $\begin{array}{c}\text { Realize } \\
d\end{array}$ & $\stackrel{(+/-}{)}$ & $\begin{array}{c}\text { Achievem } \\
\text { ent }\end{array}$ & \\
\hline \multirow[t]{7}{*}{ Wonorejo } & Socialization and RKM & 634817183 & & & 6337 & achieved & $26 \%$ & 253.48 & 345 & 92 & achieved & $44 \%$ \\
\hline & Volunteers & 607647 & & 6067 & 40 & achieved & $11 \%$ & 242.68 & 270 & 27 & achieved & $43 \%$ \\
\hline & FGD RK & 616649 & & 6157 & 33 & achieved & $13 \%$ & 246.28 & 264 & 18 & achieved & $41 \%$ \\
\hline & PS & 616661 & & 6157 & 45 & achieved & $15 \%$ & 246.28 & 272 & 26 & achieved & $42 \%$ \\
\hline & Tim PS & 616631 & & 6157 & 15 & achieved & $10 \%$ & 776468 & & 308 & Achieved & $53 \%$ \\
\hline & Election of Members of the MFI & 24632498 & & 6157 & 35 & achieved & $40 \%$ & 985.12 & 1135 & 150 & achieved & $72 \%$ \\
\hline & Preparation of PJM & 308370 & & 6157 & 62 & achieved & $7 \%$ & 139.34 & 173 & 34 & achieved & $45 \%$ \\
\hline \multirow[t]{7}{*}{ Maharatu } & Socialization and RKM & 15070 & 1507 & 1835 & 328 & achieved & $12 \%$ & 602.8 & 166 & 769 & Achieved & $42 \%$ \\
\hline & Volunteers & 15071636129 & & & $\begin{array}{c}1507 \\
0\end{array}$ & achieved & $12 \%$ & 602.8 & 682 & 79 & achieved & $42 \%$ \\
\hline & FGD RK & 22402282 & & 15470 & 42 & achieved & $15 \%$ & 937 & 896 & 41 & achieved & $42 \%$ \\
\hline & PS & 16271671 & & 16270 & 44 & achieved & $11 \%$ & 650.8 & 730 & 79 & $\begin{array}{c}\text { Completio } \\
\text { ns }\end{array}$ & $43 \%$ \\
\hline & Tim PS & 16271665 & & 16270 & 38 & achieved & $10 \%$ & 848 & 814 & 34 & achieved & $51 \%$ \\
\hline & Election of Members of the MFI & 65086538 & & 16270 & 30 & achieved & $40 \%$ & 2603.2 & 2645 & 42 & achieved & $41 \%$ \\
\hline & Preparation of PJM & 814855 & & 16270 & 41 & achieved & $5 \%$ & 325.4 & 371 & 46 & $\begin{array}{c}\text { Completio } \\
\text { ns }\end{array}$ & $46 \%$ \\
\hline \multirow[t]{7}{*}{$\begin{array}{l}\text { Sidomulyo } \\
\text { Timur }\end{array}$} & Socialization and RKM & 18671 & 1867 & 1893 & 26 & achieved & $10 \%$ & 746.84 & 786 & 39 & achieved & $42 \%$ \\
\hline & Volunteers & 15251534 & & 15251 & 9 & achieved & $10 \%$ & 610.04 & 616 & 6 & Reached & $40 \%$ \\
\hline & FGD RK & 16391688 & & 16391 & 49 & achieved & $10 \%$ & 655.64 & 694 & 38 & achieved & $42 \%$ \\
\hline & PS & 16351657 & & 16351 & 22 & achieved & $10 \%$ & 654.04 & 679 & 25 & achieved & $41 \%$ \\
\hline & Tim PS & 16351658 & & 16351 & 23 & achieved & $10 \%$ & 839 & 818 & 21 & achieved & $51 \%$ \\
\hline & Election of Members of the MFI & 65406560 & & 16351 & 20 & achieved & $40 \%$ & 2616.16 & 2637 & 21 & achieved & $40 \%$ \\
\hline & Preparation of PJM & 818839 & & 16351 & 21 & achieved & $5 \%$ & 327.02 & 347 & 20 & achieved & $42 \%$ \\
\hline
\end{tabular}




\subsection{Analysis Quality Improvement of Infrastructure Development}

The implementation of community-based infrastructure in the District of Marpoyan Damai is $55.75 \%$ compared with those not based society. This means that any activities undertaken mainly PNPM Urban infrastructure activities are much cheaper because of the community-based, in addition to utilizing public funds BLM also contribute in terms of the funds that is self funding from the public. Besides the quality of his work is much better results, because the people themselves who do the infrastructure work ranging from planning, implementation, monitoring and evaluation.

In District of Marpoyan Damai, the proposed infrastructure activities so much from the beginning of BLM fund budget in 2009 until 2010. This type of infrastructure activities proposed in the form of environmental quality improvement activities, such as:

1. Roads, which consists of a dirt road, the concrete road paving blocks, cementing and stockpiling gravel.

2. Drainage, consisting of tertiary channel and the environment, household waste, including of rehabilitation and improvement.

3. Bridge, such as construction of box culvert and bridge.

4. Health Facilities: development Posyandu

5. Clean Water, forming of a wellbore

Number of proposed infrastructure development activities in the district of Marpoyan the Peace, proved the level of the needs of society in terms of the environment is very high. Each proposal submitted community activities directly realized by PNPM Urban as a facilitator of each activity. of 2008 before the PNPM Mandiri in District Marpoyan peaceful, just society as an object and not directly involved in the development process in his village. From 2009 until now the community has been the subject of such development.

Communities in the District of Marpoyan Damai directly involved in the overall development process. With PNPM Urban was shown to accelerate the development of infrastructure for bebasis community and in accordance with the needs of the community itself.In addition, the presence of PNPM Urban can foster social capital of the community capital (mutual cooperation, caring, self-reliance and others) in the District Marpoyan Damai.

\subsection{Contributions Community Fund on Financing for Development Infrastructure}

Effectiveness PNPM Urban to accelerate infrastructure development can be seen in terms of funding. In this case will be compared between "financing capabilities through BLM (APBN and APBD) with the ability to finance the allocation of public funds to infrastructure development". Based on the theory of effectiveness, the ability of the funds will be directly proportional to the achievement of objectives (Wahab, 2004). In this case the goal is defined PNPM Urban mean acceleration of infrastructure development. Comparison between expenditure on infrastructure financing between BLM PNPM Urban with Governmental Funds people in the District of Marpoyan Damai can be seen from Figs 1 and 2.

Graph shows the contribution of BLM and nongovernmental funds to finance infrastructure in the District of Marpoyan Damai. BLM is a stimulant of government funds donated to the community to improve the Human Development Index (HDI) so that people become self-reliant so that they can overcome poverty. With this stumulan funds can raise awareness and public concern that arise volunteers from each village. Contributions from the community in the form of self-help funds donated in support of community development programs of PNPM Urban.

Graph in 2009 until 2010 funds BLM stimulant proven to increase public awareness, it can be seen from the number of self-donated funds public infrastructure development. Comparison of BLM with funds nongovernmental in 2009-2010 can be seen in Fig 3.

From a comparison chart of the infrastructure financing can be seen that the government has been successful in the last 2 years through PNPM Urban in the district of Marpoyan Damai to raise public awareness of development so that makes a society that previously powerless (poor) become more empowered to independent society. In this case the non-governmental funds increased in 2010. For example, in the construction of road infrastructure, non-governmental funds in 2009 reached $14 \%$ of the BLM. In 2010 the fund comes community towards road infrastructure increased by $31 \%$ from government funds budgeted BLM. The average increase in funding nongovernmental year from 2009 to 2010 of $22.5 \%$

PNPM Urban is divided into 3 activities (Tridaya) that environmental activities / infrastructure, social as well as economic. BLM initiated the distribution of funds for infrastructure projects, ie by $70 \% 20 \%$ and socially productive economy rolling by $10 \%$ Actual construction of infrastructure in District of Marpoyan Damai of BLM fund is equal to $70 \%$ coupled with an average improvement of community self-help funds of $22.5 \%$ was $92.5 \%$ This means the realization of infrastructure development in the District of Marpoyan Damai is 92.5\%with the National Community Empowerment Program (PNPM) Urban. These indications show that PNPM Urban can realize the proposed activities of the public infrastructure.

From Table 5 and Table 6 infrastructure improvement can be seen as an example of the road network, before their PNPM Urban (2006-Year of 2007) compared to after the PNPM Urban (2009Year of 2010).

From Fig 4 can be seen an increase in the road infrastructure in the District Marpoyan Peace. The condition of paved roads increased by $13.2 \%$ paved 
roads and dirt roads no increase $(0 \%$. The average increase in the road before their PNPM Urban in District Marpoyan Damai is $4.4 \%$

From Fig 5, it can be seen that the road infrastructure is increasing with the PNPM Mandiri. The condition of paved roads increased by $19.4 \%$ the condition of roads paved roads increased by $28.8 \%$ while the ground to be drastically reduced in the amount of $59.2 \%$ The average increase in the quality of infrastructure before the PNPM Urban program is only 4.4\%per year, after the PNPM Urban average increase in the quality of infrastructure to $35.8 \%$ This indication shows that infrastructure as a sample of road infrastructure, the quality of the road surface be toincreased significantly by the PNPM Urban is in District Marpoyan Peace.

Results of interviews with stakeholders relevantPNPM Urban which consists of KSM, PNPM Urban Consultant, Member of MFIs, with a sample of 66 samples. can be seen in Table 7 .

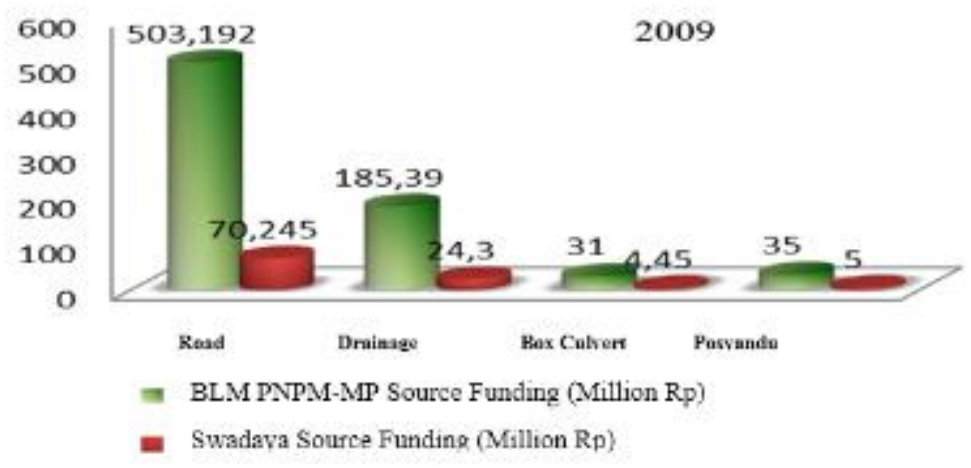

Fig 1. Graph of Infrastructure Financing in 2009

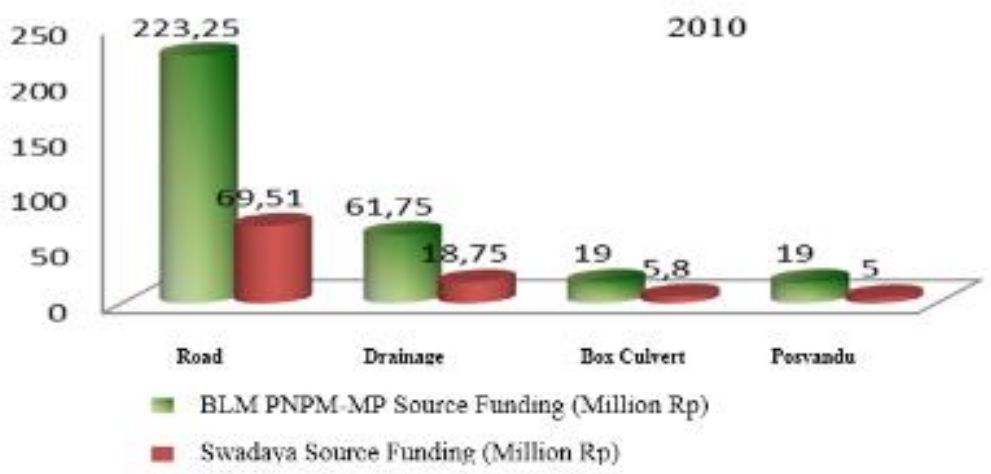

Fig 2. Graph Infrastructure Financing in 2010

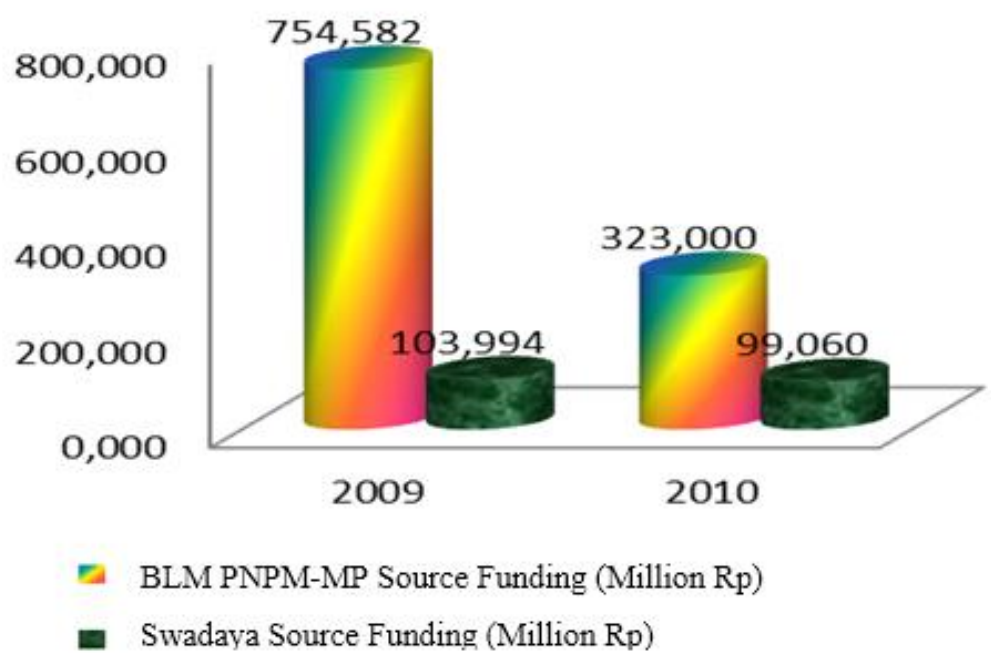

Fig 3. Comparison Chart Infrastructure Financing Through BLM with Governmental Funds. 
Table 5. Length of Road by Type of Surface (Km) in District Marpoyan Damai 2006-2007

\begin{tabular}{lcccccc}
\hline \multirow{2}{*}{ Village } & \multicolumn{3}{c}{ Year 2006 } & \multicolumn{3}{c}{ Year 2007 } \\
\cline { 2 - 7 } & Asphalt & Compaction & Land & Asphalt & Compaction & Land \\
\hline Tangkerang Tengah & 24 & 10 & 41 & 29 & 10 & 41 \\
Tangkerang Barat & 22 & 12 & 27 & 28 & 12 & 27 \\
Maharatu & 16 & 23 & 29 & 16 & 23 & 26 \\
Sidomulyo Timur & 8 & 21 & 22 & 8 & 21 & 19 \\
Wonorejo & 9 & 18 & 21 & 9 & 18 & 21 \\
Total & 55 & 130 & 129 & 55 & 130 & 112 \\
\hline
\end{tabular}

Source: District of Marpoyan Damai In 2006, 2007

Table 6. length of Road by type of Surface $(\mathrm{Km})$ in the District of Marpoyan Damai Year 2007-2010

\begin{tabular}{|c|c|c|c|c|c|c|c|c|c|}
\hline \multirow[b]{2}{*}{ Village of } & \multicolumn{3}{|c|}{ the Year 2007} & \multicolumn{3}{|c|}{ Year 2009} & \multicolumn{3}{|c|}{ Year 2010} \\
\hline & $\begin{array}{c}\text { Aspha } \\
\text { It }\end{array}$ & hardened & Land & $\begin{array}{c}\text { Aspha } \\
\text { It }\end{array}$ & hardened & Land & Asphalt & hardened & Land \\
\hline $\begin{array}{l}\text { Tangkerang } \\
\text { Tengah }\end{array}$ & 29 & 10 & 41 & 38 & 18 & 16 & 38 & 18 & 26 \\
\hline $\begin{array}{l}\text { Tangkerang } \\
\text { Barat }\end{array}$ & 28 & 12 & 27 & 33 & 16 & 16 & 33 & 16 & 16 \\
\hline Maharatu & 29 & 16 & 23 & 38 & 17 & 16 & 38 & 17 & 16 \\
\hline $\begin{array}{l}\text { Sidomulyo } \\
\text { Timur }\end{array}$ & 8 & 21 & 31 & 13 & 19 & 31 & 22 & 13 & 19 \\
\hline Wonorejo & 21 & 9 & 18 & 28 & 13 & 3 & 0 & 28 & 14 \\
\hline Total & 129 & 55 & 130 & 168 & 77 & 67 & 168 & 168 & 78 \\
\hline
\end{tabular}

Source: District of Marpoyan Damai In 2007 until 2010

Table 7. Interviews Results of Respondents

\begin{tabular}{|c|c|c|c|c|}
\hline \multirow{2}{*}{ Respondents } & \multicolumn{4}{|c|}{$\begin{array}{c}\begin{array}{c}\text { Rate the effectiveness of the infrastructure improvement seen from the realization of } \\
\text { development }\end{array}\end{array}$} \\
\hline & Not Effective $(<20 \%)$ & $\begin{array}{l}\text { Effective Enough } \\
(20 \%-40 \%)\end{array}$ & $\begin{array}{l}\text { Effective }(40 \%- \\
70 \%\end{array}$ & Very effective $(>70 \%)$ \\
\hline MFI & - & 2 & 4 & 10 \\
\hline KSM & - & 5 & 9 & 32 \\
\hline Consultants PNPM MP & - & - & - & 4 \\
\hline Total & - & 7 & 13 & 46 \\
\hline
\end{tabular}

Source: Analyse Result in 2011

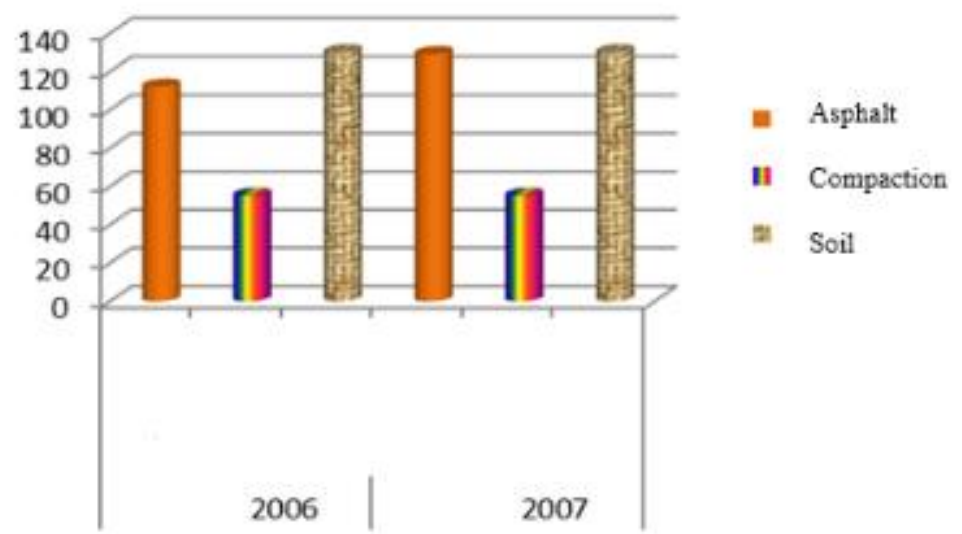

Fig 4. Graph Improving the Quality of Road Infrastructure in Sub Marpoyan Peace Before PNPM Urban 


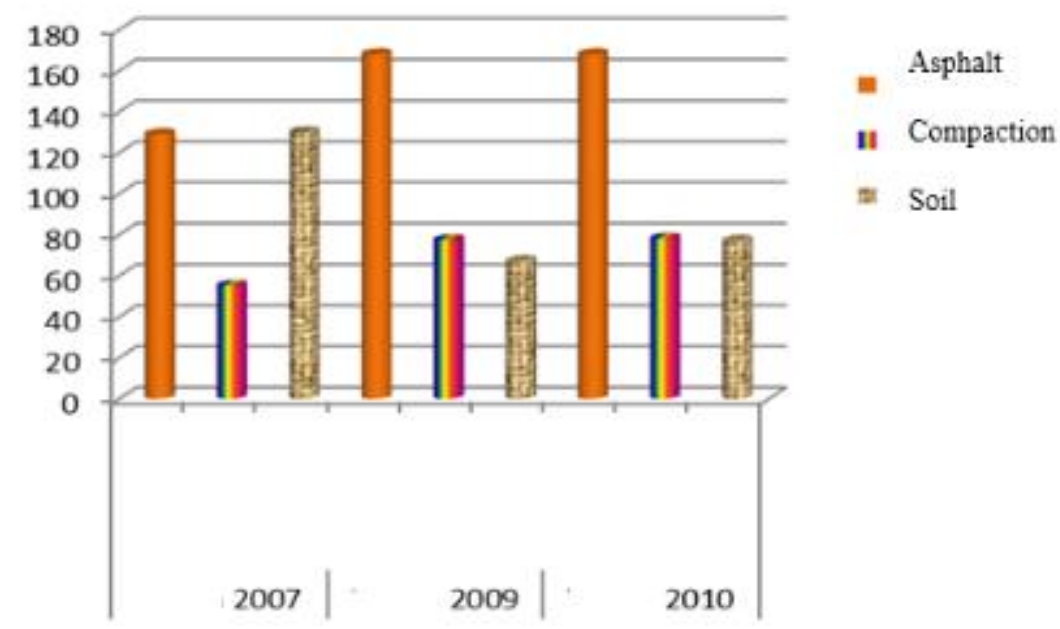

Fig 5. Graph Improving the Quality Infrastructure in the District of Marpoyan Damai After PNPM MP.

\subsection{Geology and Regional Planning}

Geological condition of research area consist of alluvium Sand, Gravel, Clay, Peat Swamp, Plant Remain in Quaternary age. There are two anticline in this research area, those western section cut Sidomulyo Timur, around the area Beringin Indah and in the South of Maharatu. There is an inferred fault with direction Northwest-Southeast in the middle area of research area cut of Sidomulyo Timur and Maharatu. Fig 6 shows a map of geological research area.
Stream-flow patterns that developed in the study dominated parallel type. This flow pattern is generally formed on a slightly steep topography caused by the presence of anticline in the region. Fig 7 shows a map of the study area drainage patterns.

Undulating topography of the research area cause by anticline and fault need special observation for land-use planning, drainage, airports, water supply and urban area. Fig 8 shows a map of land use and administration of research area.

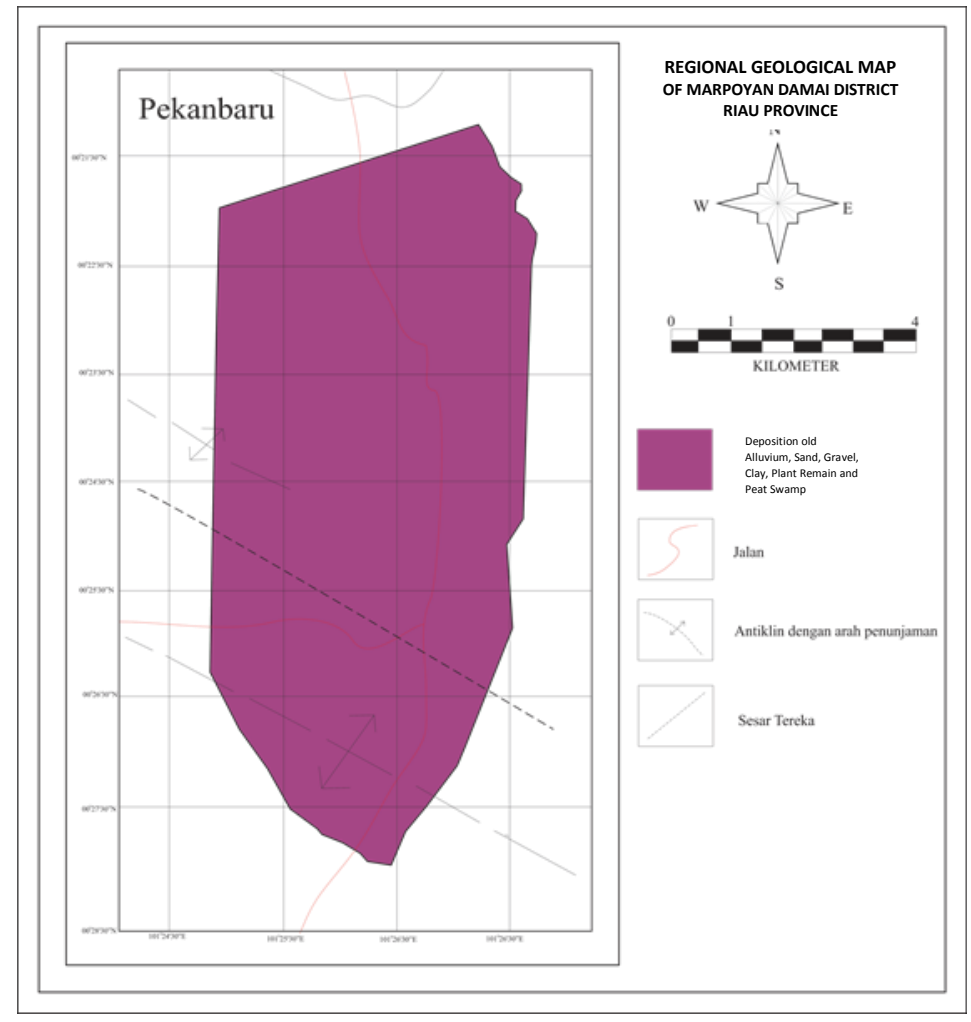

Fig 6. Geological Regional Map of research area. 


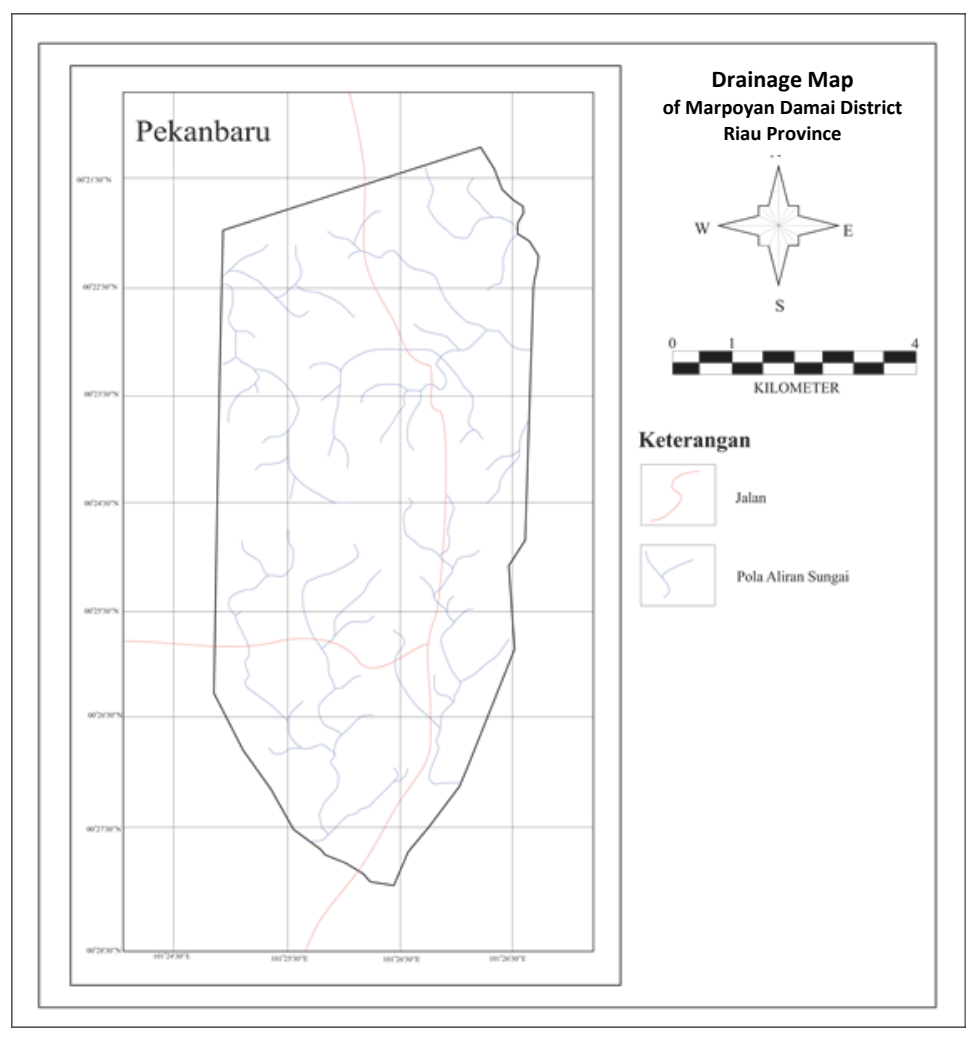

Fig7. Drainage pattern Map of the study area

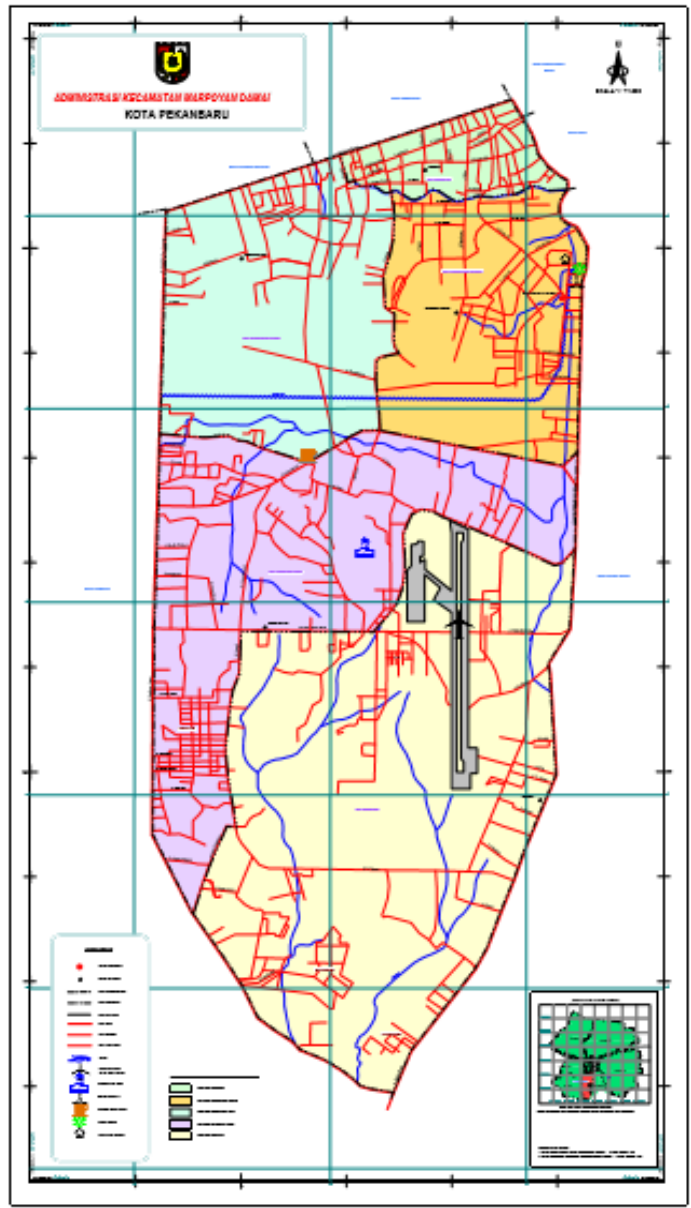

Fig 8. Land use Use and Administration Map of research area. 


\section{Conclusion}

PNPM Urban highly effective against the increase in infrastructure development in the District of Marpoyan Damai Pekanbaru. It can be seen from the realization of infrastructure development with PNPM MP 92.5\% These indications show that any proposed development of the public infrastructure can be realized by PNPM Urban. Improved infrastructure is quite significant with the PNPM Urban compared to before the program is running. The quality of the road surface before the PNPM MP (2006-2007) average increase in the quality of the road is only $4.4 \%$ After the PNPM MP (2009-2010), the average increase in the quality of the road surface of $35.8 \%$ In addition, the implementation of community-based infrastructure proved cheaper 55.75\% compared with those not based society. With PNPM Urban was shown to accelerate the development of infrastructure for community-based and according to the needs of society itself. Undulating topography of the research area cause by anticline and fault need special observation for land-use planning, drainage, airports, water supply and urban area.

\section{References}

Cahyaningsih, Catur. 2016. "Hydrology Analysis and Rainwater Harversting Effectiveness as an Alternative to Face Water Crisis in Bantan Tua Village Bengkalis District-Riau." Journal of $\begin{array}{llll}\text { Dynamics } & 1 & \text { (1): }\end{array}$ doi:10.21063/JoD.2016.V1.1.27-30.

Mairizki, Fitri, and Catur Cahyaningsih. 2017. "Ground Water Quality Analysis in the Coastal of Bengkalis City Using Geochemistry Approach" 7 (2): 2010-11.

Putra, Dewandra Bagus Eka, and Tiggi Choanji 2016. "Preliminary Analysis of Slope Stability in Kuok and Surrounding Areas." Journal of Geoscience, Engineering, Environment, and Technology 1 (1): 41-44.

Suryadi, Adi. 2016. "Fault Analysis to Determine Deformation History of Kubang Pasu Formation at South of UniMAP Stadium Hill, Ulu Pauh, Perlis, Malaysia." Journal of Geoscience, Engineering, Environtment, and Technology 1 (1): 1-6.

Yuskar, Yuniarti. 2016. "Geo-Tourism Potential of Sand Bars and Oxbow Lake at Buluh." Journal of Geoscience, Engineering, Environment, and Technology 1 (1): 59-62.

Arikunto, Suharsimi., 1998. Manajemen Penelitian, edisi baru. Penerbit Rineka Cipta. Jakarta.

Depdiknas., 2003. Kamus Besar Bahasa Indonesia, Edisi Ketiga. Penerbit Balai Pustaka. Jakarta.

Effendy, Onong Uchjana., 2003. Ilmu,teori dan filsafat komunikasi. PT.Citra Aditya Bakti. Bandung.

George Odunga Obare., 2013. Strategic Positioning of Marketplaces and learning Institution as Digital Village Centres for rural Empowerment and Development in Bondo District, International journal of business and social Research Vol. 3 No. 9 Uday Tower Gulshan-1 Dhaka-1212, Bangladesh.

Kuncoro, Mudrajad., 2004. Otonomi dan Pembangunan Daerah. Penerbit PT. Erlangga, Jakarta.

Nawawi, Hadari. 1998. Metode Penelitian Bidang Sosial. Gadjah Mada University Press.

Sedarmayanti., 2001, Sumber Daya Manusia dan Produktivitas Kerja; Bandung: CV. Mandar Maju.

Sugiyono., 2006. Statistika untuk Penelitian. Penerbit CV. Alfabeta. Bandung.

Sumaryadi, I Nyoman., 2005. Perencanaan Pembangunan Daerah Otonom dan Pemberdayaan Masyarakat. Penerbit Citra Utama. Jakarta.

Suryono, Agus., 2001. Teori dan Isu Pembangunan. Malang, Universitas Malang Press.

Todaro, Michael, P., 2000. Pembangunan Ekonomi di Dunia Ketiga, Erlangga, Jakarta.

Tri Wahyu Rejekiningsih., 2011. Identifikasi faktor penyebab kemiskinan di Kota Semarang dari Dimensi Kultural, Jurnal Ekonomi Pembangunan Vol.12 No.1, UMS Surakarta.

Wahab, Solichin Abdul., 2004. Analisis Kebijaksanaan : Dari Formulasi ke Implementasi Kebijaksanaan Negara. Penerbit Bumi Aksara. Jakarta. 